\title{
SOME IMPLICATIONS FOR USING A DIAGNOSTIC TEST IN ENGLISH LANGUAGE COURSES AT POST-SECONDARY LEVEL
}

ABSTRACT. This paper addresses a relatively new type of testing in the English language classroom called diagnostic test(ing). This type of test is used to accelerate students' performance during English language courses at the University of Priština's Faculty of Philosophy in Kosovska Mitrovica. The purpose of this test is to help teachers determine students' English language skills and to give an outlook into areas where students exhibit weaknesses and need to work on during the course.

KEY WORDS: diagnostic test; English language courses; post-secondary level; students; teachers.

\section{INTRODUCTION}

Online dictionaries define 'diagnosis' as: a) the art or act of identifying a disease from its signs and symptoms; b) the decision reached by diagnosis; c) investigation or analysis of the cause or

\footnotetext{
natasabakicmiric@yahoo.com

mirjana.loncar.vujnovic@pr.ac.rs

Рад је примљен 3. фебруара 2019, а прихваћен за објављивање на састанку Редакције 3борника одржаном 18. марта 2019.
} 
nature of a condition, situation, or problem; and d) a statement or conclusion from such an analysis (Bakić-Mirić, 2012, p. 15).

If we apply a part of this definition under $b$ ) "the decision reached by diagnosis" to language teaching, it might not be as precise as when it is applied in medicine where it is used to identify a disease or a disorder in the human body. In the broadest sense, when applied in the foreign language acquisition it refers to any practice that requires diagnosis on the current state of a student's progress or ability in a particular area of language. Since each student encounters problems in learning a foreign language, they (just like patients who come to a doctor's office) require a diagnosis from the teacher to determine weakness(es) in certain language areas at the onset of instruction.

For instance, junior year students of education studies, psychology, and history at the University of Priština's Faculty of Philosophy in Kosovska Mitrovica choose English language as one of their elective courses (which is the core curriculum requirement). The initial diagnostic test results (the diagnostic test is administered during the second lesson of the semester and after the introductory lesson during which students' communication skills in English are tested) demonstrate that their communication and writing skills are very poor (in 20 out of 20 students writing skills rank 1 on the scale from 1 to 5). Nevertheless, their listening, reading and understanding skills (shown by the diagnostic test) rank as improvable (in 20 out of 20 students listening, reading, and understanding English rank 3 on the scale from 1 to 5 ). On the other hand, students of psychology ( 30 out of 30 students) are ranked moderately higher - their communication, listening and reading skills rank 3 while writing skills still remain their weak point and rank 1 . Students of history ( 15 out of 15 students) on the scale from 1 to 5 rank 3 for listening skills, 2 for communication skills and reading skills and 1 for writing skills (Table 1.).

\begin{tabular}{|c|c|c|c|c|}
\hline DEPARTMENTS & $\begin{array}{c}\text { COMMUNICATION } \\
\text { SKILLS }\end{array}$ & $\begin{array}{c}\text { LISTENING } \\
\text { SKILLS }\end{array}$ & READING SKILLS & WRITING SKILLS \\
\hline $\begin{array}{c}\text { PSYCHOLOGY } \\
\text { (TOTAL OF 30 STUDENTS) }\end{array}$ & 3 & 3 & 3 & 1 \\
\hline
\end{tabular}

TABLE 1: RANKING BASED ON THE RESULTS OF THE DIAGNOSTIC TEST ADMINISTERED AT THE ONSET OF INSTRUCTION. 
Some Implications for Using a Diagnostic Test in English Language Course...

\begin{tabular}{|c|c|c|c|c||}
\hline $\begin{array}{c}\text { EDUCATION STUDIES } \\
\text { (TOTAL OF 20 STUDENTS) }\end{array}$ & 1 & 3 & 3 & 1 \\
\hline $\begin{array}{c}\text { HISTORY (TOTAL OF 15 } \\
\text { STUDENTS) }\end{array}$ & 2 & 3 & 2 & 1 \\
\hline
\end{tabular}

TABLE 1: RANKING BASED ON THE RESULTS OF THE DIAGNOSTIC TEST ADMINISTERED AT THE ONSET OF INSTRUCTION.

\section{THE PURPOSE OF DIAGNOSTIC TEST}

Regardless of the context in which English (or any other) language is used, mistakes are mostly accepted and tolerated because students communicate in a language that is not their native. Nonetheless, teachers oftentimes require more exertion, interest, and motivation from their students to learn the language instead of developing an intensive course that would, at the same time, also serve as a remediate course for students (Perrin, 2009, p. 50). This sort of scenario almost always calls for the diagnostic test and it is a reason why Gillian Brown and George Yule have focused their attention to diagnostic procedures instead of standardized placement tests:

"Until we have some diagnostic procedures, the teacher can only continue to test comprehension, not to teach it. We need to move to a position where the teacher is able to recognize particular patterns of behavior in listening manifested by an unsuccessful listener and to provide exercises for the student which will promote superior patterns of behavior (superior strategies)." (Brown \& Yule, 1999, p. 286)

This paragraph represents the gist of Brown and Yule's argument. Traditional placement tests actually do not measure a student's skill in a language but only superficially measure the language performance achieved by rote learning. This means that 80 out of maximum 100 points on the test is purely quantitative. What these two researchers suggest is that the teacher does not need a points total for each student to plan a successful course but qualitative data or specific areas where the students exhibit weakness(es) and need to work on in order to improve those areas.

Incidentally, Mousavi postulates that "diagnostic tests are the reverse side of achievement tests in the sense that while the interest of the achievement test is in success, the interest in the diagnostic 
test is in failure, what has gone wrong, in order to develop remedies" (Mousavi, 2000, p. 70).

Evidently, a diagnostic test is usually tailor-made based on the needs of a particular class (only after the initial diagnosis is made during the first lesson of the semester during which the teacher insists on communication interaction as a stress-free mode of assessment for students) (see Appendix on page 97 for a diagnostic test sample). When given at the onset of instruction, a diagnostic test, together with performance in class, can help teachers determine both strengths and/or weaknesses of their students (Perrin, 2009 , p. 50) and determine the type of diagnostic strategies they can use during the course of instruction for appropriate lesson planning to help struggling students "fill the gaps" in language and improve, respectively.

\section{THREE EFFECTIVE WAYS OF DIAGNOSING AND IMPROVING COMMUNICATION AND WRITING SKILLS - AUTHENTIC CLASSROOM EXAMPLES}

Broadly speaking, testing and assessment are an integral part and one of the most important requirements in education. At the core of any assessment and testing is the teacher's ability to examine students' performance and test outcomes, and to quickly and accurately produce adequate, unbiased, and diagnosed feedback about students' advancement (Bakić-Mirić 2012, p. 18).

To do this effectively, the teacher should distinguish one or two areas for students to work on during the English language course to achieve improvement. In our case, two distinguished areas for junior year students of education studies, psychology and history at the Faculty of Philosophy in Kosovska Mitrovica are communication and writing skills. A good way to start working on these two areas is to assign each student to deliver a ten-minute Power Point Presentation on a self-chosen topic related to their major in front of the whole class. For instance, education management for the students of education studies, insomnia for the students of psychology studies, and ancient Greece for the students of history studies. The goal of this exercise is to improve both communication and presentation skills. 
After each presentation an adequate feedback or diagnosis is given by the teacher (on grammar and vocabulary) and by the peers (on the content). Following teacher's feedback or diagnosis, students deliver one presentation during every next lesson of the semester for the teacher to measure their improvement. After each presentation, both the teacher and the peers give the diagnosis. Interestingly, all students agree in favor of doing Power Point presentations as a way to improve their communication and presentation skills (despite the fact that the test outcome for communication skills is 1 for some students).

As far as improving writing skills goes, the students are asked to produce a piece of writing in form of a short analytical essay on given prompt(s) and/or a summary of reading excerpt(s) under exam conditions during each lesson (Table 2.).

\begin{tabular}{||l|l|}
\hline \multicolumn{1}{|c|}{ SHORT ANALYTICAL ESSAY PROMPTS } & \multicolumn{1}{|c|}{ SUMMARY OF A READING EXCERPT } \\
\hline problem you'd like to solve. & $\begin{array}{l}\text { 1. Hollywood doesn't actually invent many new } \\
\text { superheroes. Superman, Judge Dredd, Batman } \\
\text { and the others already "existed" before Holly- } \\
\text { wood discovered them. These three all come from } \\
\text { comic magazines. The first Batman story came } \\
\text { out in 1939! So Batman has now been defending } \\
\text { the people of Gotham City for over 80 years! } \\
\text { There have been several Batman movies, with } \\
\text { different stars including Val Kilmer, George } \\
\text { Clooney and Christian Bale. How long can it last? } \\
\text { Superman is even older: he dates from about } \\
1932 \text { (the exact year is not certain). Even Judge } \\
\text { Dredd is a familiar figure; he first appeared in } \\
\text { England in 1977. } \\
\text { Hollywood's biggest superheroes live in the fu- } \\
\text { ture. That is not really surprising. Hollywood has } \\
\text { fallen in love with special effects, and the future } \\
\text { allows great spectacular special effects. Besides, } \\
\text { people today are frightened about the future. } \\
\text { Things do not always look good; perhaps we will } \\
\text { need characters like Batman and Judge Dredd in } \\
100 \text { years' time. Perhaps we even need them to- } \\
\text { day! }\end{array}$ \\
\hline
\end{tabular}

TABLE 2: EXAMPLES OF WRITING PROMPTS AND READING EXCERPTS 


\begin{tabular}{|c|c|}
\hline $\begin{array}{l}\text { 2. The lessons we take from obstacles we } \\
\text { encounter can be fundamental to later } \\
\text { success. Write about an obstacle that } \\
\text { you have encountered and how it im- } \\
\text { pacted your life. }\end{array}$ & $\begin{array}{l}\text { 2. It is not made of silicon; and it is not a river val- } \\
\text { ley; but forgetting that, Silicon Valley is probably } \\
\text { the most famous valley in the world. Although it } \\
\text { is not the place where the first computer was } \\
\text { built (that was Manchester, England), Silicon Val- } \\
\text { ley, near San Francisco, was the birthplace of the } \\
\text { modern computer industry. } \\
\text { For this, we can say thank you to scientists at the } \\
\text { universities in California, and to the Hippies of } \\
\text { the } 1960 \text { 's. } \\
\text { It was in the nineteen-sixties that Ameri- } \\
\text { can "youth culture" really began. California, of } \\
\text { course, already existed; but the Sixties Genera- } \\
\text { tion rediscovered it. } \\
\text { At the time there were really two different forms } \\
\text { of youth culture; the "Beach Boy" culture on the } \\
\text { one hand, and the anti-establishment hippies } \\
\text { and radical students on the other hand; and they } \\
\text { all dreamed of California. } \\
\text { For the Beach Boys, that meant southern Califor- } \\
\text { nia, where they could sing about surfing and cars; } \\
\text { for the Hippies and radicals, it meant San Francis- } \\
\text { co, "flower power" and revolutionary new ideas. } \\
\text { The campuses at Berkeley and Stamford, near } \\
\text { San Francisco, were hot-beds of new ideas, new } \\
\text { technology, new culture, and new ways of living. }\end{array}$ \\
\hline $\begin{array}{l}\text { 3. Reflect on a time when you chal- } \\
\text { lenged an idea or a belief. }\end{array}$ & $\begin{array}{l}\text { 3. Christmas cards are a big tradition in the Eng- } \\
\text { lish-speaking world. In } 2017 \text {, people in Britain } \\
\text { sent and received about } 900 \text { million cards. That's } \\
\text { an average of about twelve cards for every per- } \\
\text { son, from tiny babies to the oldest grandparents. } \\
\text { The number of cards that are sent around Britain } \\
\text { causes an annual headache for the postal service. } \\
\text { Each year, the postal service has to take on sea- } \\
\text { sonal staff to help with the extra mail, and post- } \\
\text { al sorting offices are stretched to their maximum } \\
\text { capacity and sometimes beyond it. } \\
\text { In } 1994, \text { the service handled about } 1.6 \text { billion } \\
\text { cards! - about } 25 \text { cards per person in Great Brit- } \\
\text { ain, including children!). In spite of advertise- } \\
\text { ments telling people to "Post Early for }\end{array}$ \\
\hline
\end{tabular}

TABLE 2: EXAMPLES OF WRITING PROMPTS AND READING EXCERPTS 


\begin{tabular}{||l|l||}
$\begin{array}{l}\text { 4. Discuss an accomplishment that initi- } \\
\text { ated your growth. }\end{array}$ & $\begin{array}{l}\text { Christmas", few people get round to sending off } \\
\text { their cards before December 10th; and from that } \\
\text { point on, the postal service slows down. } \\
\text { Until the age of faxes, emails and social media, } \\
\text { the pre-Christmas period often caused a lot of } \\
\text { problems for firms and industry, as "urgent" let- } \\
\text { ters and documents took several days to reach } \\
\text { their destination by post, slowed down by the } \\
\text { mass of Christmas mail! } \\
\text { (Retrieved from https://linguapress.com/in- } \\
\text { ter.htm on January 22nd, 2019) }\end{array}$ \\
$\begin{array}{ll}\text { 5. Share an essay topic of your choice. } \\
\text { (Retrieved from https://www.thought } \\
\text { co.com/common-application-es- } \\
\text { say-prompts-788383 on January 22nd, } \\
\text { 2019) }\end{array}$
\end{tabular}

TABLE 2: EXAMPLES OF WRITING PROMPTS AND READING EXCERPTS

To measure improvement, the teacher should always correct the short essay and/or a summary and attach a diagnostic sheet to it (in medicine, diagnostic sheet is a fact sheet about diagnosis and treatment issued by a doctor). For instance, teachers can comment on areas of language to be improved (such as verb forms, irregular verbs, articles, prepositions etc.) instead of marking or underlining mistakes in red without explanation and/or solution. This sort of medical approach to language teaching defines and determines deficiencies in the area of student error that will ultimately result in language improvement.

Today, since most teachers teach English language courses in large groups, they should be able to offer diagnosis to all students in class but, unfortunately, they can achieve real improvement in language with only a few because large groups are a big obstacle for teachers, which disable them to help students in need to actually improve their weak areas after the initial testing and subsequent diagnosis. This, practically, leaves only advanced students to benefit from diagnostic tests and perhaps reach native-speaker level. Practice has shown that only a few of the students who frequent the English language course at post-secondary level are able to deliver presentations, present poster sessions, and take part in discussions at international conferences and meetings later on.

Finally, it is mostly these students who benefit the most from the initial diagnostic test and tailor-made English lessons (Willis, 2009, p. 70; Richards, 1999, pp. 10-15; Larsen-Freeman, 2000, p. 75). 


\section{CONCLUSIONS}

The primary goal of diagnostic tests is to obtain relevant information about students' language skills and, according to the authors, it should be based on direct evaluation of students' communicative skills and assessment of content knowledge during the first lesson of the semester.

Despite its shortcomings-such as large groups of students and subsequent inability of teachers to work on the diagnosis after the initial testing and help students improve in their weak areas-a diagnostic test is very important for English language classes at post-secondary level primarily because diagnostic testing not only indicates students' weakness(es) in certain areas of language and helps teachers in creating tailor-made solutions for particular language problems to be worked on in class but it also helps those few students (whose level of English is quite high) approximate to an even higher level upon the completion of the course.

\section{DIAGNOSTIC TEST}

The initial diagnostic English language test (administered at the onset of instruction) consists of 5 parts (or separate tests). Time limit for each part (test) is approximately 30 to 45 minutes.

This is a diagnostic test sample that can be used in any English language classroom (more tests can be found at http://www.iearnpk.org/P4L-YES/english_diagnostic_test.htm). As a point of note, each student is administered a test at the appropriate level of difficulty which is determined by the teacher during and after the first introductory lecture and based on students' communication skills.

\section{ENGLISH DiAgNostic TEST - I}

NAME

PART I

A. Circle the LetTer that CORRESPONDS to THE CORRECT VERB FOR THE SENTENCE THAT IS GIVEN. 
EXAMPLE: We

a) buy b) buyed c) bought a television yesterday.

1. Both doors closed.

a) is b) were c) was

2. John sat down and his books on the table.

a) put b) puts c) is putting

3. This pen to me.

a) belong $\mathrm{b}$ ) belongs $\mathrm{c}$ ) is belonging

4. Mary and Tom at the party last night?

a) Was b) Were c) Are

5. There nobody at home.

a) was b) were c) be

6. I enjoy on trips.

a) to go b) going c) go

7. After leaving the office, he home.

a) has gone b) went c) was gone

8. Last night we dinner at home.

a) have eaten b) eat c) ate

9. Have you ever a) drove b) drives c) driven a Cadillac?

10. I was so tired, I down on the bed.

a) lain b) lay c) laid

11. Jim has a cold.

a) catches b) caught c) catched

12. The cup when I dropped it.

a) broken b) break c) broke a b c

B. CIRCLE THE LETTER THAT CORRESPONDS TO THE CORRECT PREPOSITION FOR THE SENTENCE THAT IS GIVEN.

EXAMPLE: I'm surprised you! a) at b) with c) for

1. They arrived New Orleans last night.

a) at b) in c) for 
2. He lives 509 Augusta Boulevard.

a) at b) on c) in

3. Beware

a) for b) to c) of the dog!

4. He is very interested old musical instruments.

a) of b) by c) in

5. You can depend him.

a) on b) by c) with

6. They arrived Kennedy Airport at 6:30.

a) in b) to c) at

7. I don't agree

a) to b) with c) at

8. She is very good

a) in b) on c) at

C. CHOOSE A SUITABLE ANSWER FOR EACH OF THE QUESTIONS.

1. Are my friend and I early? Yes,

a) we are b) you are c) they are.

2. Must the Smiths go out today? Yes,

a) she must b) we must c) they must

3. Is the Taurus a good car? Yes,

a) that is. b) it is. c) she is.

4. How are you?

a) Not at all. b) Fine, thank you. c) You're welcome.

5. Am I disturbing you?

a. No, here you are. b) No, I hope not. c) No, not at all.

6. Will you please come this way?

a) Of course. b) Really! c) You're right.

7. May I come in?

Please do. b) Very well, thank you. c) Yes, thank you.

8. Thank you for helping me!

a) You're welcome. b) Thanks. c) Excuse me. 
D. Circle the CORReCt Alternative.

1. He is

a) a b) an c) any honest man.

2. Helen didn't want to go

a) also b) neither c) either

3. He spends time on his homework.

a) much b) many c) often

4. Do you like for breakfast?

a) tea b) the tea c) a tea

5. Didn't he tell you ?

a) where was the key b) where the key was c) the key was where

6. I would like to a request.

a) do b) tell c) make

7. We have been here

a) for b) during c) since

8. Henry is taller George.

a) from b) as c) than three months.

9. George is coming to the party,

a) does he? b) won't he? c) isn't he?

10. I _-_-_ not come to this class yesterday.

a) can b) could c) should

E. CHOOSE THE CORRECT ALTERNATIVE.

1. Did you walk by the sea yesterday?

a) Yes, I walked. b) Yes, I did walk. c) Yes, I did.

2. it yet?

a) Have you did b) Have you done c) You have done

3. pass me the salt, please? ok, here you are.

a) You will b) Can you c) You can

4. Gerald the tickets.

a) already bought b) had already buyed c) has bought already 
5. What language ?

a) speak they b) do they speak c) does they speak

6. Richard to a girl when I saw him.

a) talked b) was talking c) did talk

7. When he will you tell him to meet me in the lobby?

a) arrives b) is going to arrive c) will arrive

8. Which picture when you came in?

a) were they looking at b) have they looked at c) are they looking at

9. Teachers are lucky because they work in the summer.

a) haven't to b) mustn't c) don't have to

10. There isn't at home.

a) no one b) anyone $c$ ) any people

F. VOCABULARY

Circle the letter that corresponds to the correct word(s).

1. The opposite of sharp is

a) bright b) old c) dull

2. Right away means

a) later b) immediately c) to the right

3. To pick out something is to

a) need it b) want it c) choose it

4. We often use the word hard as the opposite of

a) new b) easy c) fine

5. When you are cautious, you are

a) careful b) brave c) happy

6. Currently means

a) recently b) occasionally c) at present

7. To attempt means

a) to fail b) to try c) to be bad

8. He visited her daily means 
a) all day b) every day c) almost every day

9. Hence is used to mean

a) however b) meanwhile c) therefore

10. I'd rather study means that I

a) always study b) like to study c) prefer to study

11. At last means

a) soon b) finally c) at the end

12. Little by little means

a) a small amount b) soon c) gradually

13. To make up one's mind is to

a) remember something $b$ ) decide something $c$ ) to invent something

14. When a person attends class, he

a) listens to b) assists c) goes to

15. When we waste money, we

a) invest b) save c) spend it

16. If the Joneses purchase a house, they

a) buy b) enlarge c) rent

17. If Jill blushed, she

a) reddened b) sighed c) yawned

18.When you pay a huge sum of money, you pay

a) an enormous b) a modest c) a tiny amount of money.

19. When I cannot prevent something, I cannot

a) cure b) help c) stop it

20. If someone says to you "Look out!" this means

a) look out the window b) wait c) be careful

\section{PART II - LISTENING COMPREHENSION}

A. YOU WILL BE GIVEN THREE DESCRIPTIONS FOR EACH OF THE WORDS BELOW. CIRCLE THE LETTER THAT CORRESPONDS TO THE CORRECT ANSWER. WE WILL DO THE EXAMPLE TOGETHER.

EXAMPLE: chair

a $\quad b \quad c$ 
1. policeman

2. photographer

3. department store

4. kitchen

5. cushion

6. library a b $\quad c$

a $\quad b \quad c$

a $\quad b \quad c$

a $\quad b \quad c$

a $\quad b \quad c$

a $\quad b \quad c$

Listen to the short dialogues. Then circle the letter that corresponds to the correct answer. Where are the people who are speaking?

1. a) at the supermarket b) at the gym c) at school

2. a) at the market b) at a party c) at a swimming pool

3. a) in the kitchen b) in a restaurant c) at the supermarket

4. a) at the theatre b) at a disco c) at the beach

5. a) in the bedroom b) at a clothing store c) in the closet

6. a) at home b) in the classroom c) at the doctor's office

\section{PART II OF THE DIAGNOSTIC TEST}

The following should be read to the students clearly and fairly slowly. Read twice. Do not repeat too many times. It is best if the dialogue is read by two people.

For each of the words on your papers, three descriptions are given. Circle the letter that corresponds to the correct answer. We will do the example together.

EXAMPLE: chair a) furniture for sleeping $b$ ) furniture to sit on c) furniture for the bathroom

The correct answer is: $b$ ).

1. policeman

a) a man who comes from another country

b) a man who keeps law and order

c) a man who drives taxis 
2. photographer

a) a person who uses a camera to take pictures

b) the art of taking pictures with a camera

c) a picture made by using a camera

3. department store

a) the same as a block of houses

b) a storage room where they keep spare parts

c) a store where they sell many different ?products

4. kitchen

a) a part of the house where you keep the car

b) a storage room in a factory where they keep?spare parts

c) a room in the house where you cook

5. cushion

a) something you use to cover yourself

b) something you have in an armchair or sofa to? rest against

c) something you like to eat

6. library

a) a place where you go to borrow money

b) a place where you go to buy books

c) a place where you go to borrow books

B. LISTEN TO THE SHORT DIALOGUES THAT WILL BE READ. THEN PUT A CIRCLE AROUND THE LETTER THAT CORRESPONDS TO THE PLACE WHERE THE CONVERSATION IS TAKING PLACE. WHERE ARE THE PEOPLE?

1. Jane: Hi! Wow, that test was really hard!

Frank: Yeah. I didn't have time to study.

a) at the university b) in the kitchen c) at home

2. Mary: Have you tried the dip?

Alice: Yes. I had some with the potato chips.

Mary: Would you like some more punch?

a) at a party b) at the shopping mall c) at the food court

3. Mrs. Johnson: Boy, are these prices high, especially when you're cooking for a big family. 
Mrs. Saunders: I agree. Maybe we should buy chicken instead of beef.?

a) at the restaurant b) at the grocery store c) at the butcher's shop

4. Bill: The waves are big today. Joe: They sure are. I'm not going in by myself.

a) at the lake b) at the beach c) by the pool

5. Kris: This looks like my size. Could I try it on?

Mrs. Nelson: Sure, the dressing room is on your left.

a) at the theater b) at the department store c) at the flea market

6. Ken: Mrs. Turner, I didn't do my homework because I didn't understand it.?

Mrs. Turner: Everyone sit down now. Ken, I'll explain it as soon as everyone is quiet.

a) at the library b) in the classroom c) in the school yard

REFERENCES Anonym. (2019). Linguapress. Retrieved from https://linguapress.com/in ter.html on January 22, 2019.

Bakić-Mirić N. (2012). Significance of Creating a Custom Diagnostic English Language Test in English for Specific Purposes Course at the University of Niš Medical School. Acta Medica Medinae. 15 (1), 15-19.

Brown G. and Yule G. (1999). Teaching the Spoken Language. Cambridge: Cambridge University Press. Larsen-Freeman D. (2000). Techniques and Principles in Language Teaching. Oxford: Oxford University Press.

Mousavi S. A. (2012). An Encyclopedic Dictionary of Language Testing (5th edition). Tehran: Rahnama Press.

Perrin G. 2009. Diagnostic procedures in English language teaching. Modern English Teacher. 18 (1), 49-54

Richards J. (1999). Language Teaching Matrix: Curriculum, Methodology and Materials. Cambridge: Cambridge University Press.

Willis D. (2009). Doing Task-based Teaching. Oxford: Oxford University Press. 
НАТАША М. БАКИЋ-МИРИЋ

МИРЈАНА Н. ЛОНЧАР-ВУЈНОВИЋ

УНИВЕРЗИТЕТ У ПРИШТИНИ СА ПРИВРЕМЕНИМ СЕДИШТЕМ

У КОСОВСКОЈ МИТРОВИЦИ, ФИЛОЗОФСКИ ФАКУЛТЕТ

КАТЕДРА ЗА ЕНГЛЕСКИ ЈЕЗИК И КњИЖЕВНОСТ

РЕЗИМЕ

ИМПЛИКАЦИЈЕ ПРИМЕНЕ ДИЈАГНОСТИЧКОГ ТЕСТА У НАСТАВИ ЕНГЛЕСКОГ ЈЕЗИКА У ВИСОКОМ ОБРАЗОВАҢУ

Овај рад анализира употребу дијагностичког теста за побољшање резултата студената у настави енглеског језика на факултету. Сврха наведеног теста је да наставницима помогне приликом процене нивоа знања енглеског језика и пружи комплетан преглед области језика у којима студенти показују недовољан ниво знања. Након процене знања, путем дијагностичког теста, студенти могу почети да раде на јачању области у којима су показали недовољан ниво знања како би укупно знање енглеског језика значајно унапредили до краја курса.

КљУчНЕ РЕчИ: дијагностички тест; енглески језик; високо образовање; студенти; наставници.

Овај чланак је објављен и дистрибуира се под лиценцом Creative Commons Ауторство-Некомерцијално Међународна 4.0 (СС BY-NC 4.0 |

https://creativecommons.org/licenses/by-nc/4.0/).

This paper is published and distributed under the terms and conditions of the Creative Commons Attribution-NonCommercial International 4.0 licence (CC BY-NC 4.0 | https://creativecommons.org/licenses/by-nc/4.0/). 